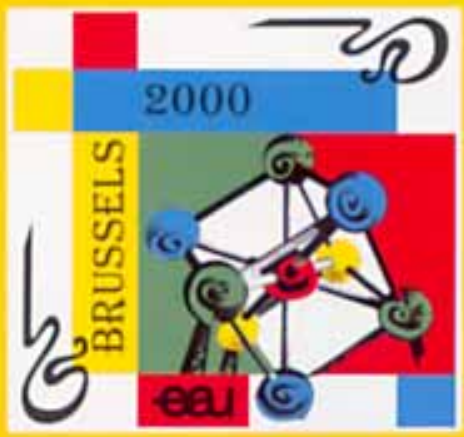

Released March 2000

ISSN $0302-2838$

37cuppl 2) 1-175 (2000)

Suppleasent for wahscriben free of charge
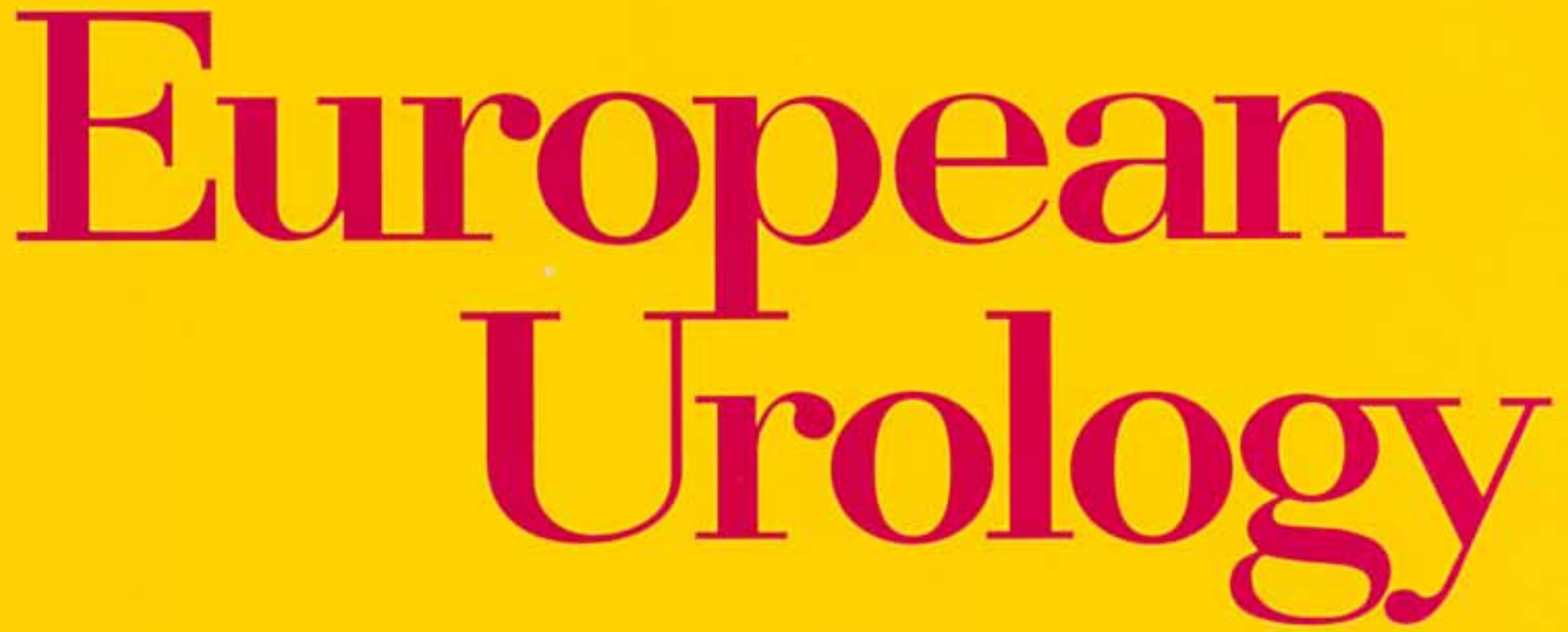

\title{
XVth Congress of the European Association of Urology
}

April 12-15, 2000, Brussels

\section{Editor:}

Members of the EAU Scientific Committee of the XVth EAU Congress:

P. Alken, Mannheim

W. Artibani, Modena

L. Boccon-Gibod, Paris

J. Breza. Bratislava

C. Chapple, Sheiffield

E. Debruyne, Nimegen

P. Ekman, Stockholm

R. Kirby, London
P. Puppo, Genoa

C. Schulman, Brussels

E. Solsona, Valencia

U. Studer, Berm

P. Van Cangh, Brussels

H. Van Poppel, Louvain

A. Zlotta, Brussels

Members of the EAU Video Committee of the XVth EAU Congress:

G. Carmignani, Genoa

W. A. De Sy, Ghent

A. Nagy, Debrecen
H. Villavicencio, Barcelona

M. Wirth, Dresden

M. Zerbib, Paris 
This issue contains the Abstracts of the

XVth Congress of the

European Association of Urology

April 12-15, 2000 Brussels

and is not available online for technical reasons. 